Article

\title{
An Impedimetric Biosensor Based on Ionic Liquid-Modified Graphite Electrodes Developed for microRNA-34a Detection
}

\author{
Ece Kesici ${ }^{1,2}$, Ece Eksin 1,2 (D) and Arzum Erdem 1,2,* (D) \\ 1 Analytical Chemistry Department, Faculty of Pharmacy, Ege University, Bornova 35100, Turkey; \\ e.kesici93@gmail.com (E.K.); eceksin@hotmail.com (E.E.) \\ 2 Biotechnology Department, The Institute of Natural and Applied Sciences, Ege University, \\ Bornova 35100, Turkey \\ * Correspondence: arzum.erdem@ege.edu.tr or arzume@hotmail.com; Tel.: +90-232-311-5131; \\ Fax: +90-232-388-5258
}

Received: 11 July 2018; Accepted: 21 August 2018; Published: 31 August 2018

\begin{abstract}
In the present work, an impedimetric nucleic acid biosensor has been designed for the purpose of detection of microRNA (miRNA). Ionic liquid (1-butyl-3-methylimidazolium hexafluorophosphate (IL))-modified chemically activated pencil graphite electrodes (PGEs) were used for the sensitive and selective detection of miRNA-34a. After covalent activation of the PGE surface using covalent agents (CAs), the ionic liquid (IL) was immobilized onto the surface of the chemically activated PGE by passive adsorption. The electrochemical and microscopic characterization of the IL/CA/PGEs was performed by electrochemical impedance spectroscopy (EIS), cyclic voltammetry (CV) and scanning electron microscopy (SEM). DNA probe concentration, miRNA target concentration, and also the hybridization time and wet adsorption time were optimized by using the EIS technique. Then, the hybridization occurred between specific DNA probes and miRNA-34a was immobilized onto the surface of the IL/CA/PGEs. The impedimetric detection of miRNA-DNA hybrid was performed by EIS. The detection limit (DL) was calculated in a linear concentration range of $2-10 \mu \mathrm{g} / \mathrm{mL}$ miRNA-34a target, and it was found to be $0.772 \mu \mathrm{g} / \mathrm{mL}$ $(109 \mathrm{nM})$ in phosphate buffer solution (PBS) and $0.826 \mu \mathrm{g} / \mathrm{mL}(117 \mathrm{nM})$ in diluted fetal bovine serum (FBS). The selectivity of impedimetric biosensor for miRNA-34a was also tested against to other non-complementary miRNA sequences both in buffer media, or diluted FBS.
\end{abstract}

Keywords: ionic liquid; pencil graphite electrode; microRNA; electrochemical impedance spectroscopy; fetal bovine serum; nucleic acid hybridization

\section{Introduction}

Nucleic acid analysis using biosensing strategies has been an attractive topic in many fields, including gene analysis, clinical disease diagnosis, biological, environmental, pharmaceutical and forensic applications [1-6]. Nucleic acid recognition technologies combined with electrochemical transducers have been applied to the diagnostic area. Wide-scale genetic testing requires the development of easy-to-use, fast, inexpensive, miniaturized analytical devices.

Ionic liquids (ILs) like 1-butyl-3-methylimidazoliumhexafluorophosphate are known as lowmelting organic salts that are mostly liquid at room temperature. Due to their unique properties such as low measurable vapor pressure, high thermal stability and conductivity, good solvating properties, non-volatility, low toxicity and biocompatibility, they have been used in different fields, including development of electrochemical biosensors [7-15]. Ren et al. [15] developed a chronocoulometric DNA sensor that based on polyaniline nanotubes (PANINTs) and ionic liquid (IL)-doped screen-printed 
electrodes. Eksin et al. [13] developed chitosan/ionic liquid modified pencil graphite electrodes (CHIT/IL/PGEs) in order to perform enhanced electrochemical monitoring of nucleic acid, and study the interaction of the anticancer drug, mitomycin C (MC) and calf thymus double stranded DNA (dsDNA). She et al. [14] detected hydroquinone using a carbon paste electrode enhanced by a hydrophobic IL. Sengiz et al. [16] designed IL modified pencil graphite electrodes (IL/PGEs) for electrochemical monitoring of DNA sequence selective hybridization related to Microcystis spp. (MYC). miRNAs are small nucleotides in 19-25 bp. that are noncoding RNA molecules found in eukaryotic cells $[17,18]$. The importance of miRNA itself is due to the complicated regulatory functions it plays in various life processes and its close relationship with some diseases. The majority of diseases (cancer, heart failure, vascular disease, diabetes, etc.) has been related to the regulation of miRNAs due to their influence on the fundamental cellular process including cell proliferation, apoptosis, differentiation, and migration $[2,19,20]$. miRNA-34a in particular is related to cancer initiation, oncogenesis, and tumor response to treatments [21]. According to the literature, it was found that miRNA-34a could be used as biomarker for diagnosis of cancer [22,23], cardiovascular disease [24] and Alzheimer's disease [25].

Northern blotting, isothermal exponential amplification-based methods and rolling cycle amplification-based methods are applied as the conventional miRNA detection techniques which are expensive, complicated, hardly employed and time consuming for on-site measurement. In contrast to these conventional techniques, the electrochemical detection techniques in combination with biosensor technologies have more advantages such as time savings, simple analysis by offering a specific recognition process and requiring a small amount of sample. Efficient immobilization of oligonucleotides onto the surface of the analysis platform has been one of the key features for the successful design of biosensor platforms [1-6,26]. Electrochemical techniques offer a reliable and fast response to achieve sensitive and selective detection and to miniaturize the fabricated biosensors. Electrochemical impedance spectroscopy (EIS) is one of the sensitive analytical techniques that can rapidly detect small changes in reactive surfaces by using a transducer and enlarging the signal with an amplifier, making EIS one of the more suitable detection methods for nucleic acid biosensors [27]. Additionally, EIS allows one to perform analyses in complex solutions, such as serum.

To the best of our knowledge, this is the first study in the literature which presents the impedimetric detection of miRNA-34a by using ionic liquid-modified chemically activated PGEs. IL/CA/PGEs are designed for the purpose of specific recognition of miRNA-34a, which is related to Alzheimer's disease $[25,28]$ and different types of cancer $[22,23,29,30]$.

First, the chemical activation of the PGE surface was performed by covalent agents in order to allow the efficient modification of the electrode surface with the IL due to its advantages; such as, its enhanced conductivity due to its stability and making sensor's surface biocompatible. The characterization of the IL-CA-modified PGEs was performed by scanning electron microscopy (SEM), electrochemical impedance spectroscopy (EIS) and cyclic voltammetry (CV). The experimental parameters, such as duration of the IL modification on the surface of the PGE, the percentage of IL, miRNA-34a specific DNA probe, miRNA-34a RNA concentration, the hybridization time and hybrid immobilization time onto the surface of IL/CA/PGEs were optimized. The detection limit (DL) of miRNA-34a was estimated, and the selectivity of the impedimetric biosensor platform was tested against to other non-complementary microRNA sequences; miRNA-155 and miRNA-181b in buffer (PBS, pH 7.40), or fetal bovine serum (FBS):PBS (1:10) diluted solution.

\section{Materials and Methods}

\subsection{Apparatus}

The electrochemical measurements including CV and EIS were carried out using an AUTOLAB PGSTAT 302 electrochemical analysis system equipped with the GPES 4.9 software package (Eco Chemie, Utrecht, The Netherlands). 
The measurements were performed with a traditional three electrode system using a disposable PGE, a platinum wire and an $\mathrm{Ag} / \mathrm{AgCl} / \mathrm{KCl} / 3 \mathrm{M}$ (BAS, Model RE-5B, W. Lafayette, IN, USA) as working, counter and reference electrode, respectively. All measurements were performed in a Faraday cage (Eco Chemie, Utrecht, The Netherlands). A model pencil (Rotring, Hamburg, Germany) was used as a holder for the graphite lead (Tombow $0.5 \mathrm{HB}$, Shinshiro, Japan). Electrical contact between the lead and pencil was provided by soldering a metallic wire to the metallic part of the pencil. The pencil lead was held vertically with $14 \mathrm{~mm}$ of the lead extruded outside and $10 \mathrm{~mm}$ of which was immersed in the solution.

\subsection{Chemicals}

The chemical linkers used for covalent attachment; N-hydroxysuccinimide (NHS) and $N$-(3-dimethylaminopropyl)- $N^{\prime}$-ethylcarbodiimide hydrochloride (EDC) were purchased from (Sigma-Aldrich, St. Louis, MO, USA). The IL (1-butyl-3-methylimidazolium hexafluorophosphate) was also purchased from Sigma-Aldrich. Other chemicals were in analytical reagent grade and supplied by Sigma (St. Louis, MO, USA) and Merck (Kenilworth, NJ, USA).

The amino linked miRNA-34a specific DNA probe, miRNA-34a RNA target (i.e., the complementary of miRNA-34a specific DNA probe), and other miRNA sequences were purchased from Ella Biotech (Planegg, Germany) as a lyophilized powder. The base sequences of the miRNAs are listed below:

miRNA-34a G specific DNA probe: (miRNA-34a G probe):

$5^{\prime}-\mathrm{NH}_{2}-\left(\mathrm{CH}_{2}\right)_{6}$-ACA ACC AGC TAA GAC ACT GCC A-3'

miRNA-34a RNA target:

5'-UGG CAG UGU CUU AGC UGG UUG U-3' (U= Urasil)

Non-complementary (NC) miRNAs:

miRNA-155:

5'-UUA AUG CUA AUC GUG AUA GGG GU-3'

miRNA-181b:

\section{5'-AAC AUU CAU UGC UGU CGG UGG GU-3'}

The stock solutions of miRNAs $(500 \mu \mathrm{g} / \mathrm{mL})$ were prepared with Tris-EDTA buffer $(10 \mathrm{mM}$ Tris-HCl, 1 mM EDTA, pH 8.0) and kept frozen. The diluted solutions of miRNAs were prepared with $50 \mathrm{mM}$ phosphate buffer containing $20 \mathrm{mM} \mathrm{NaCl}$ (PBS, pH 7.4).The CA solution was prepared freshly for each experiment by using $5 \mathrm{mM}$ EDC and $5 \mathrm{mM}$ NHS prepared in phosphate buffer solution (PBS, $\mathrm{pH}$ 7.40). Ultra-pure water was used in order to prepare all aqueous solutions.

\subsection{Procedure}

The experimental procedure consists of following steps:

(i) pretreatment of PGE $(+1.4 \mathrm{~V}, 30 \mathrm{~s})$

(ii) chemical activation of PGE surface using covalent agents (CA)

(iii) IL modification onto CA/PGE surfaces

(iv) characterization of IL/CA/PGEs

(v) hybridization of miRNA-34a specific DNA probe with miRNA-34a RNA target, or noncomplementary RNAs (miRNA-155/miRNA-181b)

(vi) immobilization of hybrid onto the surface of IL/CA modified electrode

(vii) electrochemical measurement

PGE surface activation processes were carried out at $+4{ }^{\circ} \mathrm{C}$. Other experiments were done at room temperature. A schematic representation was presented in Figure 1. 


\subsubsection{Preparation of CA Solution and Formation of Chemically Activated PGEs}

PGEs were electrochemically pretreated by applying $+1.40 \mathrm{~V}$ for $30 \mathrm{~s}$ in acetate buffer solution (ABS, pH 4.80) (Figure 1i) [6,7,13,31,32]. Each pretreated PGE was immersed into the vials containing $100 \mu \mathrm{L}$ of $5 \mathrm{mM}$ CA solution during $60 \mathrm{~min}$ to obtain activated carboxyl groups at the surface of the PGEs [31] before IL modification. Each PGEs was then rinsed with PBS for $10 \mathrm{~s}$ to remove unbound probe from electrode surface (Figure 1ii). NHS is an organic compound and after its mixing with a coupling reagent such as EDC, activated acid intermediate (CA) could be formed.

\subsubsection{Modification of IL onto the Surface of CA/PGEs}

The required amount of IL dissolved in organic solvent $N, N$-dimethylformamide (DMF) solution and then sonicated during $30 \mathrm{~min}$ at room temperature. According to the experimental conditions for preparation of IL modified electrodes previously reported by our group, each chemically activated PGE was immersed into the vials containing $100 \mu \mathrm{L}$ of IL during $15 \mathrm{~min}$ (Figure 1iii). Then, the electrodes were then allowed to dry for $30 \mathrm{~min}$ at upside position without rinsing [16].

\subsubsection{Microscopic Characterization of the Electrodes by Scanning Electron Microscopy (SEM)}

The SEM images of unmodified, CA modified, IL modified, and CA and IL modified PGEs were obtained by a Quanta 400 FEI (Thermo Fisher Scientific, Hillsboro, OR, USA), field emission scanning electron microscope (FE-SEM, Tokoyo, Japan) with the acceleration voltage $5.0 \mathrm{kV}$ with 5 , 10 and $50 \mu \mathrm{m}$ resolutions.

2.3.4. Hybridization of miRNA-34a Specific DNA Probe with miRNA-34a Target or Non-Complementary miRNAs

The miRNA-34a specific DNA probe, or miRNA-34a target or non-complementary miRNAs; miRNA-155/miRNA-181b was prepared in PBS (pH 7.40). Accordingly, the DNA probe and miRNAs were mixed and incubated at room temperature with gently mixing at $400 \mathrm{rpm}$ during 5 min for hybrid formation in solution phase (Figure 1v). Likewise, the hybridization of miRNA-34a specific DNA probe and complementary miRNA-34a RNA target, or non-complementary miRNAs was also performed in the artificial serum medium; e.g., FBS medium during 5 min at room temperature.

\subsubsection{Immobilization of DNA-RNA Hybrids onto the Surface of IL/CA/PGEs}

The chemically active and IL modified PGE was immersed into the vials containing $40 \mu \mathrm{L}$ hybrid during $30 \mathrm{~min}$ in order to immobilization of hybrid onto the electrode surface according to wet-adsorption process (Figure 1vi). Each of the electrodes was then rinsed with PBS for $10 \mathrm{~s}$ to remove unbound probe from electrode surface, and accordingly the impedimetric measurements were performed.

\subsubsection{Cyclic Voltammetry Measurements}

$\mathrm{CV}$ measurements were performed in potential range from -0.5 to $+1.30 \mathrm{~V}$ with the scan rate as $50 \mathrm{mV} / \mathrm{s}$ in a redox probe solution of $2 \mathrm{mM} \mathrm{K}_{3}\left[\mathrm{Fe}(\mathrm{CN})_{6}\right] / \mathrm{K}_{4}\left[\mathrm{Fe}(\mathrm{CN})_{6}\right](1: 1)$ prepared in $0.1 \mathrm{M} \mathrm{KCl}$. The raw datas were also treated using the Savitzky and Golay filter (level 2).

\subsubsection{Impedimetric Measurements}

In the presence of $2.5 \mathrm{mM} \mathrm{K}_{3}\left[\mathrm{Fe}(\mathrm{CN})_{6}\right] / \mathrm{K}_{4}\left[\mathrm{Fe}(\mathrm{CN})_{6}\right](1: 1)$ mixture as redox probe prepared in $0.1 \mathrm{M} \mathrm{KCl}$, EIS measurements were performed accordingly in each experimental step (Figure 1vii). At the open circuit potential of $+0.23 \mathrm{~V}$ versus $\mathrm{Ag} / \mathrm{AgCl}$ with a sinusoidal signal of $10 \mathrm{mV}$, the impedance was measured in a frequency range from $10 \mathrm{mHz}$ to $1000 \mathrm{kHz}$. The respective semicircle diameter corresponds to the charge transfer resistance $\left(R_{c t}\right)$, the values are calculated using the fitting program AUTOLAB PGSTAT 302 (FRA version 4.9, Eco Chemie, Utrecht, The Netherlands). 
All measurements are performed in triplicate by using new electrode and the relative standard deviations (RSD\%) indicate reproducibility of the results.

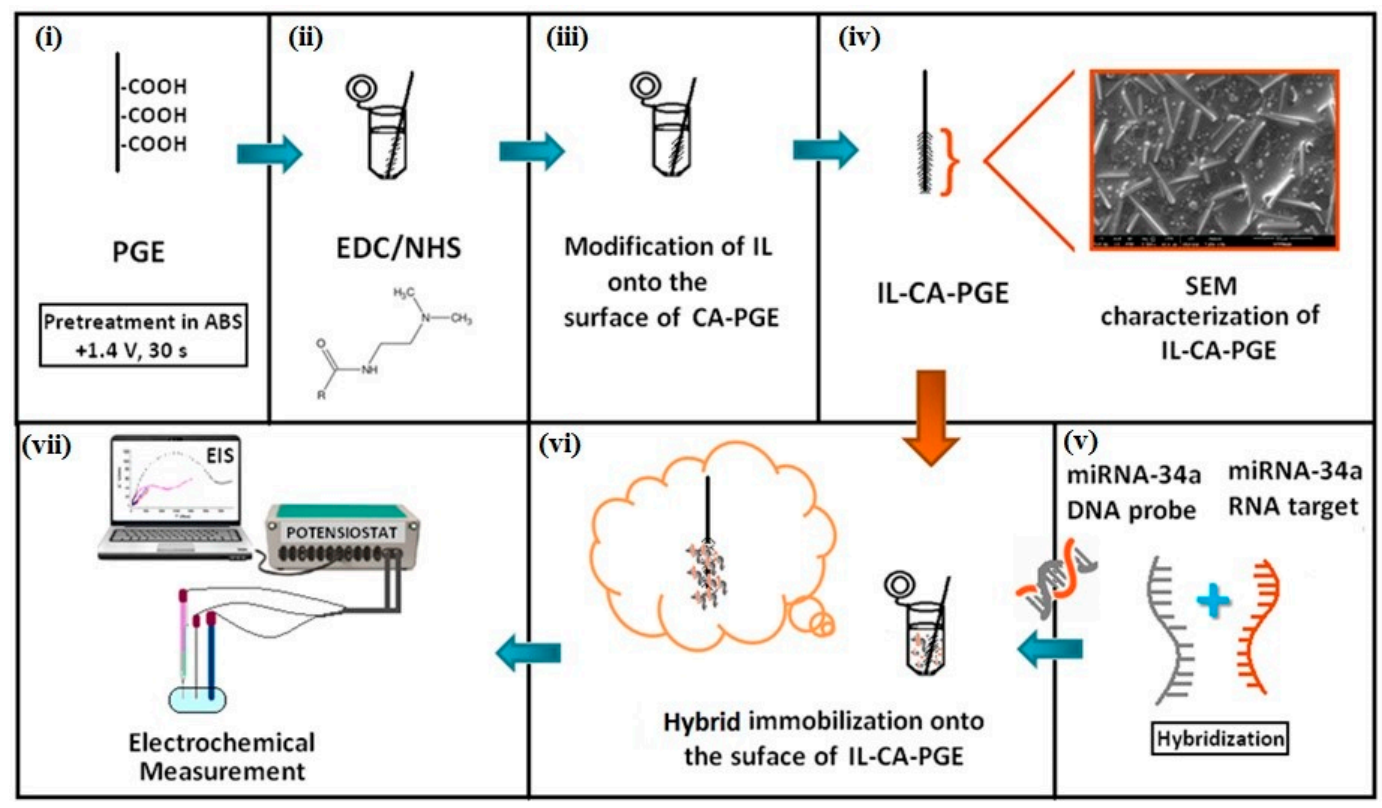

Figure 1. Experimental scheme presenting the pretreatment of PGE (i); the activation of PGE with EDC/NHS (ii), modification of IL onto the surface of CA/PGE (iii); microscobic characterization of electrodes (iv), the hybridization between miRNA-34a target and its complementary DNA probe (v); immobilization of the hybrids at the surface of IL/CA/PGE (vi); electrochemical measurement (vii).

\section{Results and Discussion}

The electrochemical surface characterization was investigated by using CV and EIS. The impedimetric surface characterization of PGE, CA/PGE and \%20 IL modified CA/PGE were performed by EIS technique in order to introduce the advantages of CA activation and IL modification onto PGE surface (Figure 2). The average $R_{\mathrm{ct}}$ values of unmodified PGE, CA/PGE, and IL/CA/PGE were measured as $103.26 \pm 23.14 \mathrm{Ohm}(\mathrm{RSD} \%, 22.41 \%, \mathrm{n}=3), 254.00 \pm 49.56 \mathrm{Ohm}(\mathrm{RSD} \%, 19.51 \%, \mathrm{n}=3)$ and $15.67 \pm 3.07(\mathrm{RSD} \%, 19.58 \%, \mathrm{n}=3)$. After IL modification onto CA/PGE surface, $93.83 \%$ decrease at $R_{c t}$ was recorded (Figure $\left.2 b, c\right)$. This decrease is consistent with the fact that the IL modification can yield an increase at the conductivity of PGE surface since there is an increase at the interfacial electron transfer occurring between the electrode and the electroactive species in solution [31].

Next, the electrochemical surface characterization of PGE, CA/PGE and IL/CA/PGE was determined by using CV as seen in Figure 3. The average anodic peak current (Ia) of PGE, CA/PGE and $20 \%$ IL modified CA/PGE was measured as $81.95 \pm 4.33 \mu \mathrm{A}(\mathrm{RSD} \%, 5.29 \%, \mathrm{n}=3), 60.07 \pm 2.68 \mu \mathrm{A}$ $(\mathrm{RSD} \%, 4.46 \%, \mathrm{n}=3)$ and $122.33 \pm 10.64 \mu \mathrm{A}(\mathrm{RSD} \%, 8.70 \%, \mathrm{n}=3)$ Figure 3. After IL modification onto CA/PGE surface $103.60 \%$ increase at anodic peak current was recorded (Figure 3b-d) due to the fact that the repulsive electrostatic interaction between IL and anionic redox $[\mathrm{Fe}(\mathrm{CN}) 6]^{3-/ 4-}$ ions at the surface of IL/CA/PGE. The role of IL is to accelerate the electron transfer and accordingly, an increase at Ia was recorded comparison to the ones obtained by PGE and CA/PGE. 


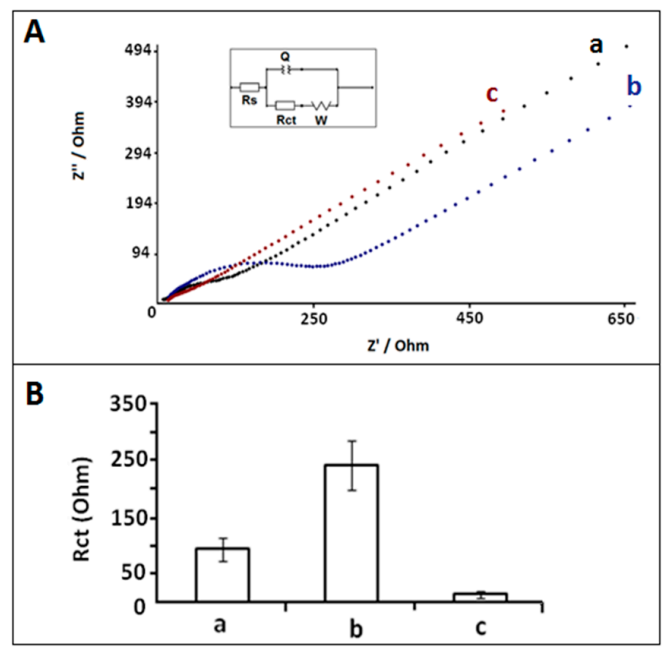

Figure 2. (A) Nyquist diagrams of (a) PGE, (b) CA/PGE, (c) IL/CA/PGE in $2.5 \mathrm{mM} \mathrm{Fe}(\mathrm{CN})_{6}{ }^{3-/ 4-}$. (B) Histograms representing the average $R_{c t}$ values of (a) PGE, (b) CA/PGE, (c) IL/CA/PGE ( $n=3$ ). Inset was the equivalent electrical model used to fit the impedance data. The impedimetric results were fitted by using an equivalent circuit model, $R(Q(R W))$ the parameters of which are listed in the text; $R_{S}$ is the solution resistance. The constant phase element $Q$ is then related to the double layer capacitance at the electrode-electrolyte interface. $R_{c t}$ is related to the charge transfer resistance at the electrode-electrolyte interface. The constant phase element $\mathrm{W}$ is the Warburg impedance due to mass transfer to the electrode surface.

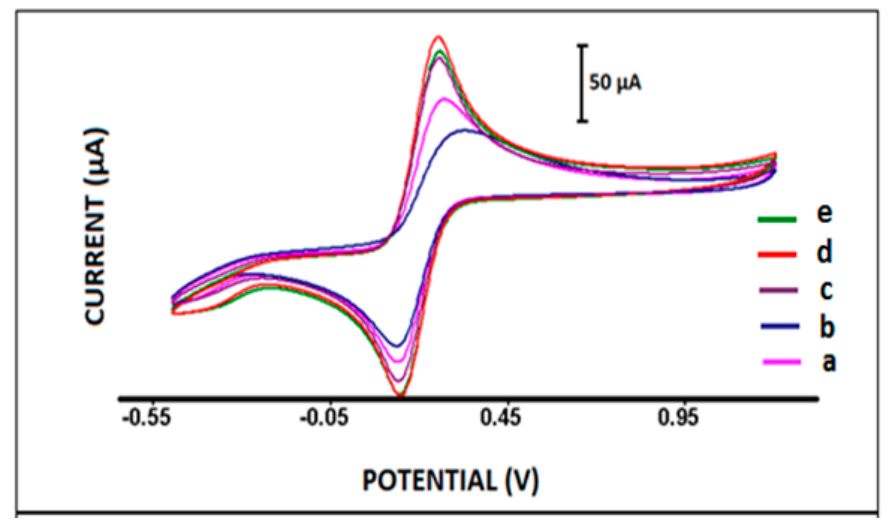

Figure 3. Cyclic voltammograms recorded in $2 \mathrm{mM} \mathrm{K}_{4}\left[\mathrm{Fe}(\mathrm{CN})_{6}\right] / \mathrm{K}_{3}\left[\mathrm{Fe}(\mathrm{CN})_{6}\right](1: 1)$ prepared in $0.1 \mathrm{M}$ KCl solution by using (a) PGE and (b) CA/PGE, \%IL modified CA/PGE (c) $10 \%$ (d) $20 \%$ (e) $30 \%$.

In order to the see the effect of IL concentration upon the average anodic peak current (Ia) to was examined in various IL concentrations; $5 \%, 10 \%, 15 \%, 20 \%, 25 \%$ and $30 \%$ and the results shown in Figure S1. The average anodic peak currents (Ia) of 5\%,10\%, 15\%, 20\%, 25\% and 30\% was measured as $112.10 \pm 4.60 \mu \mathrm{A}(\mathrm{RSD} \%, 4.11 \%, \mathrm{n}=3), 116.10 \pm 4.45 \mu \mathrm{A}(\mathrm{RSD} \%, 3.83 \%, \mathrm{n}=3), 122.33 \pm 10.64 \mu \mathrm{A}$ $(\mathrm{RSD} \%, 8.70 \%, \mathrm{n}=3), 115.10 \pm 7.00 \mu \mathrm{A}(\mathrm{RSD} \%, 6.07 \%, \mathrm{n}=3)$ and $116.23 \pm 5.37 \mu \mathrm{A}(\mathrm{RSD} \%, 4.62 \%, \mathrm{n}=3)$. The maximum increase in anodic peak current was observed at $20 \%$ IL concentration. According to the CV measurements; average anodic peak currents (Ia), anodic charge values (Qa) and calculated surface areas (A) of PGE, CA/PGE and \% IL modified CA/PGEs, 5\% IL to 30\% IL are shown in Table S1. 20\% IL modified CA/PGE was chosen as optimum IL concentration due to the maximum surface area was determined about $50 \%$. Moreover, the largest surface area as $0.38 \mathrm{~cm}^{2}$ was obtained by IL/CA/PGE in contrast to the ones of PGE and CA/PGE. Hence, it was concluded that the electroactive surface area of CA/IL/PGE increased due to the layered structure of IL in comparison to the one of CA/PGE. 
In addition, IL immobilization period onto the surface of CA/PGE was optimized by EIS in Figure S2. The average $R_{c t}$ values of unmodified PGE, CA/PGE, and IL modified CA/PGE in 15, 30 and $60 \mathrm{~min}$ were measured as $103.94 \pm 22.44 \mathrm{Ohm}(\mathrm{RSD} \%, 21.59 \%, \mathrm{n}=3), 251.06 \pm 45.51 \mathrm{Ohm}(\mathrm{RSD} \%$, $18.13 \%, \mathrm{n}=3), 19.67 \pm 4.04(\mathrm{RSD} \%, 20.55 \%, \mathrm{n}=3), 19.79 \pm 6.20(\mathrm{RSD} \%, 31,32 \%, \mathrm{n}=3)$ and $21.00 \pm 8.19$ $(\mathrm{RSD} \%, 38.98 \%, \mathrm{n}=3)$ respectively.

The highest decrease at the $\mathrm{R}_{\mathrm{ct}}$ value was obtained in the case of $15 \mathrm{~min}$ passive adsorption and it was more reproducible. Also, all detection time can be shorter here with 15 min passive adsorption time was used in further experiments.

In addition, the apparent fractional coverage $\left(Q^{I S}{ }_{R}\right)$ values were calculated according to Equation (1) given by earlier report of Janek et al. [32] to describe the surface to which the probe was attached to the surface to the surfaces of PGE, CA/PGE and IL/CA/PGE:

$$
\mathrm{Q}_{\mathrm{R}}^{\mathrm{IS}}=1-\left[\mathrm{R}_{\mathrm{ct}} \text { (bare electrode) } / \mathrm{R}_{\mathrm{ct}} \text { (modified electrode) }\right]
$$

The results are summarized in the inset of Figure S3. The highest $\mathrm{Q}^{\mathrm{IS}}{ }_{\mathrm{R}}$ was found in the presence of $1 \mu \mathrm{g} / \mathrm{mL}$ probe onto the surface of IL/CA/PGE.

In addition, the microscopic characterization of disposable graphite electrodes; unmodified PGE, CA/PGE, IL/PGE and IL/CA/PGEs was explored by SEM under the optimum conditions. The SEM images are given in Figure 4. After activation of the PGE surface by using CA agents, a brighter surface observed in contrast to the unmodified one due to the film layer at the CA modified electrode surface (Figure 4B). It was found that the surface of IL modified PGE is more homogenous than the one of unmodified PGE (Figure 4A).

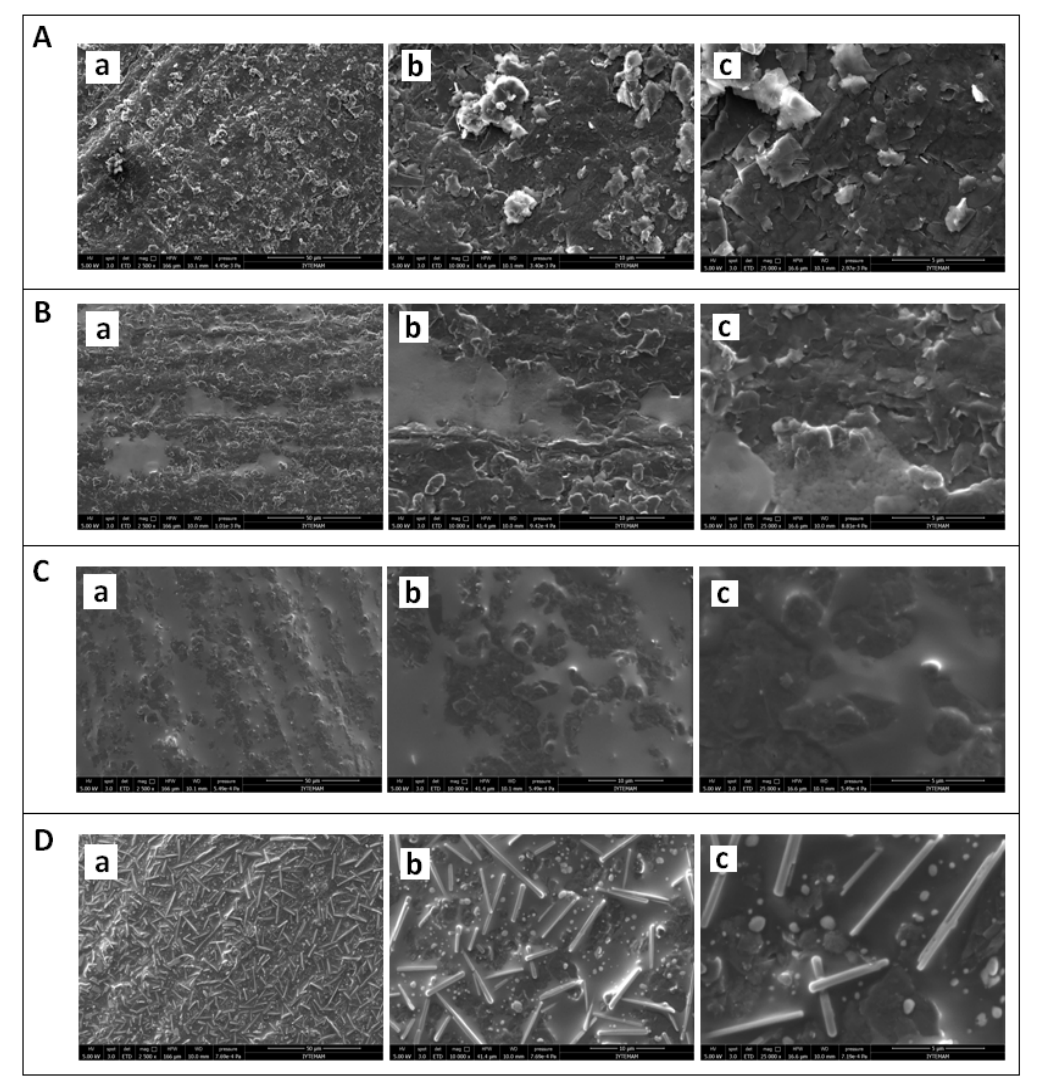

Figure 4. SEM images of (A) unmodified PGE, (B) CA modified PGE, (C) IL modified PGE, (D) CA and IL modified PGE using identical acceleration voltage as $5.0 \mathrm{kV}$ with resolution at (a) $50 \mu \mathrm{m}$, (b) $10 \mu \mathrm{m}$ and (c) $5 \mu \mathrm{m}$ respectively. 
After IL modification onto the surface of CA/PGE (Figure 4D), a more homogenous surface was obtained in contrast to the ones of CA/PGE (Figure 4B) and IL/PGE (Figure 4C).

In order to optimize the miRNA-34a DNA probe concentration, hybridization was performed in the presence of different miRNA-34a DNA probe concentrations and $10 \mu \mathrm{g} / \mathrm{mL}$ miRNA-34a target in Figure S4. The average $R_{\mathrm{ct}}$ values after pseudo-hybridization of $0.5,1.0$ and $1.5 \mu \mathrm{g} / \mathrm{mL}$ DNA probe were measured as $227.50 \pm 4.95 \mathrm{Ohm} ; 238.67 \pm 24.91 \mathrm{Ohm}$ and $344.50 \pm 45.96 \mathrm{Ohm}$, respectively. After full hybridization of $0.5,1.0$ and $1.5 \mu \mathrm{g} / \mathrm{mL}$ miRNA-34a DNA probe with $10 \mu \mathrm{g} / \mathrm{mL}$ miRNA-34a target, the average $R_{c t}$ values were measured as $689.17 \pm 83.44 \mathrm{Ohm} ; 815.00 \pm 331.31 \mathrm{Ohm}$ and $604.50 \pm 101.12 \mathrm{Ohm}$, respectively.

In the case of full hybridization between $0.5 \mu \mathrm{g} / \mathrm{mL}$ DNA probe and 34a target, the $\mathrm{R}_{\mathrm{ct}}$ value was found 2.88 times higher than the one obtained in the pseudo-hybridization. This increase at $\mathrm{R}_{\mathrm{ct}}$ value was explained by the increased negativity at the electrode surface after DNA:miRNA hybridization. Furthermore, the highest increase at $R_{c t}$ value was determined in the presence of full match hybridization case of $1 \mu \mathrm{g} / \mathrm{mL}$ miRNA-34a DNA probe with miRNA-34a target. Hence, $1 \mu \mathrm{g} / \mathrm{mL}$ was selected as optimum miRNA-34a probe concentration.

Next, the effect of hybridization time was explored based upon the sensor response. The hybridization between $1 \mu \mathrm{g} / \mathrm{mL}$ miRNA-34a DNA probe and $10 \mu \mathrm{g} / \mathrm{mL}$ miRNA34-a target was performed for various hybridization times (5, 15, $30 \mathrm{~min}$, Figure S5). After $5 \mathrm{~min}$ pseudo-hybridization of $1 \mu \mathrm{g} / \mathrm{mL}$ miRNA-34a probe, the average $R_{\mathrm{ct}}$ value was measured as $277.71 \pm 66.42 \mathrm{Ohm}$ $(\mathrm{RSD} \%=23.92 \%, \mathrm{n}=3)$. After hybridization between $1 \mu \mathrm{g} / \mathrm{mL}$ miRNA-34a DNA probe and $10 \mu \mathrm{g} / \mathrm{mL}$ miRNA-34a target, the average $\mathrm{R}_{\mathrm{ct}}$ value was 2.5 times higher than the one obtained by pseudo-hybridization $689.40 \pm 95.95 \mathrm{Ohm}(\mathrm{RSD} \%=13.92 \%, \mathrm{n}=3)$ (Figure S5). The highest increase at the $R_{\mathrm{ct}}$ value was obtained in the case of $5 \mathrm{~min}$ hybridization, thus $5 \mathrm{~min}$ hybridization time was used in further experiments.

In addition, the effect of passive adsorption time of hybrid was investigated. The miRNA-34a DNA probe $(1 \mu \mathrm{g} / \mathrm{mL})$ and $10 \mu \mathrm{g} / \mathrm{mL}$ miRNA34-a target hybrid was immobilized onto the surface of IL/CA/PGE for various passive adsorption times (5, 15, 30, $45 \mathrm{~min}$, Figure S6). After $30 \mathrm{~min}$ passive adsorption of $1 \mu \mathrm{g} / \mathrm{mL}$ miRNA-34a DNA probe and $10 \mu \mathrm{g} / \mathrm{mL}$ miRNA-34a target, the average $\mathrm{R}_{\mathrm{ct}}$ value was measured as $691.80 \pm 93.01(\mathrm{RSD} \%=13.44 \%, \mathrm{n}=3)$. This was 2.4 times higher than the one obtained by pseudo-hybridization $287.00 \pm 78.02 \mathrm{Ohm}(\mathrm{RSD} \%=27.19 \%, \mathrm{n}=3$, Figure S4). The highest increase at the $R_{c t}$ value was obtained in the case of 30 min passive adsorption.

The effect of miRNA-34a target concentration on the hybridization process based on the changes at $R_{c t}$ value was investigated. After 5 min pseudo-hybridization of $1 \mu \mathrm{g} / \mathrm{mL}$ miRNA-34a DNA probe, the average $R_{c t}$ value was found to be $342.27 \pm 97.28 \mathrm{Ohm}(\mathrm{RSD} \%=28.42 \%, n=3)$ in Figure 5 . Then, the $R_{c t}$ values were measured in the case of full hybridization between $1 \mu \mathrm{g} / \mathrm{mL}$ miRNA-34a DNA probe and miRNA-34a target at different concentrations varying from 2 to $12 \mu \mathrm{g} / \mathrm{mL}$ and the average $R_{c t}$ values were measured $433.00 \pm 134.54 \mathrm{Ohm} ; 513.50 \pm 65.76 \mathrm{Ohm} ; 565.67 \pm 32.58 \mathrm{Ohm}$; $622.00 \pm 47.48 \mathrm{Ohm}, 697.75 \pm 106.30 \mathrm{Ohm} ; 542.00 \pm 123.04 \mathrm{Ohm}$, respectively. The highest $R_{\mathrm{ct}}$ value with a good reproducibility $(\mathrm{RSD} \%=15.23 \%, \mathrm{n}=3$ ) was determined in the presence of $10 \mu \mathrm{g} / \mathrm{mL}$ miRNA-34a target. 


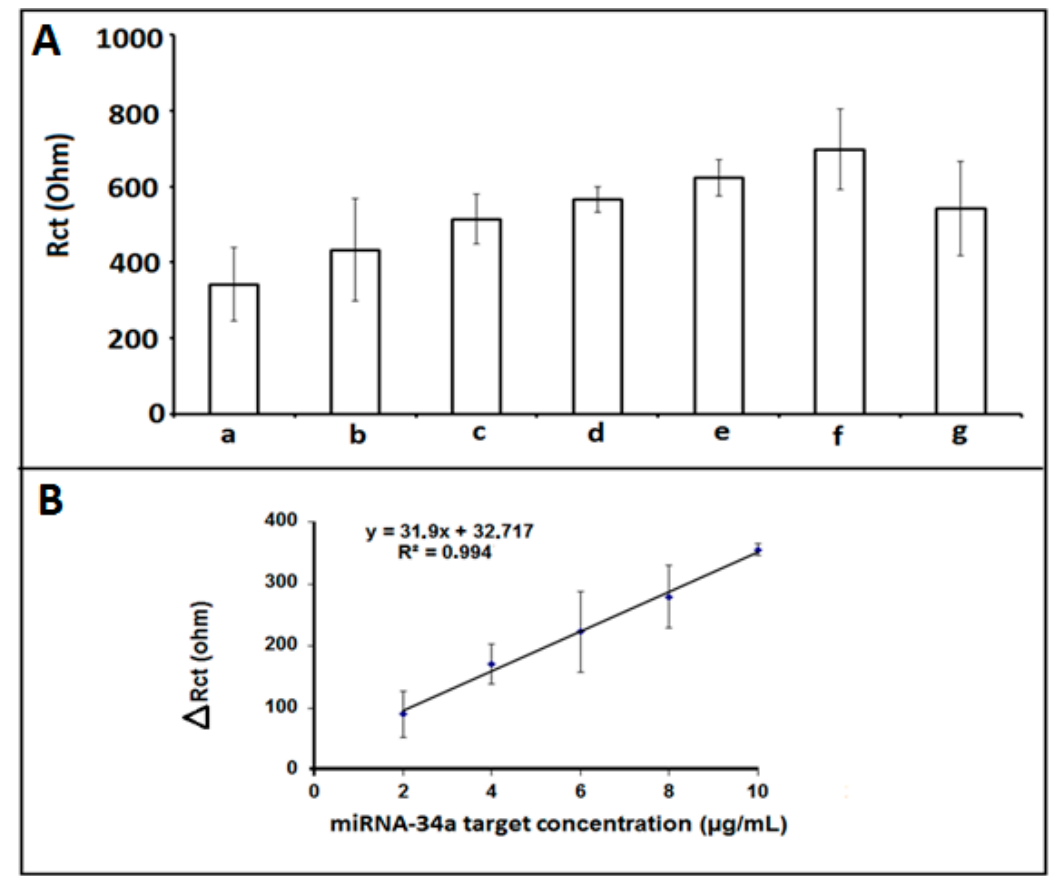

Figure 5. (A) Histograms representing the $R_{\mathrm{ct}}$ values obtained by (a) $1 \mu \mathrm{g} / \mathrm{mL}$ miRNA-34a DNA probe, after hybridization between $1 \mu \mathrm{g} / \mathrm{mL}$ miRNA-34a DNA probe and different miRNA-34a RNA target concentrations (b) $2 \mu \mathrm{g} / \mathrm{mL}$, (c) $4 \mu \mathrm{g} / \mathrm{mL}$, (d) $6 \mu \mathrm{g} / \mathrm{mL}$, (e) $8 \mu \mathrm{g} / \mathrm{mL}$, (f) $10 \mu \mathrm{g} / \mathrm{mL}$ (g) $12 \mu \mathrm{g} / \mathrm{mL}$. (B) The calibration graph obtained from $\mathrm{R}_{\mathrm{ct}}$ values measured in the presence of different concentration of miRNA-34a target, ranging $2-10 \mu \mathrm{g} / \mathrm{mL}$.

Moreover, the apparent fractional coverage values $\mathrm{Q}^{\mathrm{IS}}{ }_{\mathrm{R}}$ were calculated for hybridization between $1 \mu \mathrm{g} / \mathrm{mL}$ miRNA-34a probe and $10 \mu \mathrm{g} / \mathrm{mL}$ mirNA-34a DNA target on the surface of IL/CA/PGE according to Equation (1) described by Janek et al. [32] and found to be 0.955 (Table S2). The values of $\mathrm{Q}^{\mathrm{IS}}{ }_{\mathrm{R}}$ were higher than 0.9 , which indicated successful modification and the more coverage was obtained at the surface of hybrid between $1 \mu \mathrm{g} / \mathrm{mL}$ miRNA-34a probe and $10 \mu \mathrm{g} / \mathrm{mL}$ mirNA-34a DNA target.

The detection limit (DL) was calculated in the linear concentration range from 2 to $10 \mu \mathrm{g} / \mathrm{mL}$ (Figure 5B, inset) and it was found to be $0.772 \mu \mathrm{g} / \mathrm{mL}(4.36 \mathrm{pM}$ in $40 \mu \mathrm{L}$ sample) with a regression equation $y=31.9 x+32.717$ with the coefficient of determination $\left(R^{2}\right)$ of $R^{2}=0.994$ according to the procedure described by Miller and Miller [33]. Since the highest and more reproducible $\mathrm{R}_{\mathrm{ct}}$ was obtained in the presence of hybridization of $1 \mu \mathrm{g} / \mathrm{mL}$ miRNA-34a I probe with $10 \mu \mathrm{g} / \mathrm{mL}$ miRNA-34a target, the $10 \mu \mathrm{g} / \mathrm{mL}$ target concentration level was chosen as the optimum one for further selectivity studies.

The selectivity of the impedimetric miRNA-34a biosensor platform was tested against other microRNA sequences: miRNA-550 and miRNA-181b. In this respect, hybridization between $1 \mu \mathrm{g} / \mathrm{mL}$ miRNA-34a DNA probe and $10 \mu \mathrm{g} / \mathrm{mL}$ miRNA-34a target, or noncomplementary miRNAs was performed and the average $R_{c t}$ values recorded as $692.71 \pm 85.77 \mathrm{Ohm} ; 512.67 \pm 109.50 \mathrm{Ohm}$; $563.20 \pm 107.44 \mathrm{Ohm}$; with the RSDs\% as $12.38 \%, 21.27 \%, 19.08 \%$ (shown in Figure 6), respectively. The highest $R_{\mathrm{ct}}$ value was determined after hybridization between miRNA-34a specific probe and its complementary miRNA-34a RNA target. 


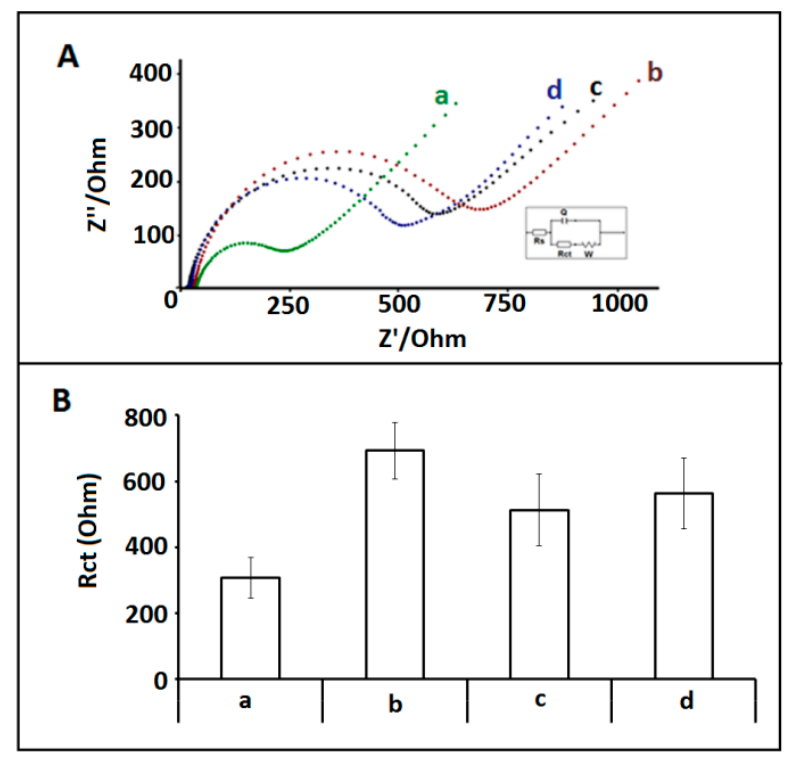

Figure 6. (A) Nyquist diagrams representing the $\mathrm{R}_{\mathrm{ct}}$ values obtained by (a) $1 \mu \mathrm{g} / \mathrm{mL}$ miRNA-34a probe modified /IL/CA/PGE, hybridization between $1 \mu \mathrm{g} / \mathrm{mL}$ miRNA-34a DNA probe and $10 \mu \mathrm{g} / \mathrm{mL}$, (b) miRNA-34a target, (c) miRNA-181b, (d) miRNA-155. (B) Histograms representing the $\mathrm{R}_{\mathrm{ct}}$ values obtained by (a) $1 \mu \mathrm{g} / \mathrm{mL}$ miRNA-34a probe modified /IL/CA/PGE, hybridization between $1 \mu \mathrm{g} / \mathrm{mL}$ miRNA-34a DNA probe and $10 \mu \mathrm{g} / \mathrm{mL}$, (b) miRNA-34a target, (c) miRNA-181b, (d) miRNA-155.

The hybridization between $1 \mu \mathrm{g} / \mathrm{mL}$ miRNA 34a DNA probe and miRNA-34a target, or non-complementary miRNAs; miRNA15a, and miRNA-660 was also performed in fetal bovine serum (FBS) medium. Firstly, the dilution ratio of FBS was investigated based on the sensor response. Different dilution ratios of FBS:PBS (1:1, 1:5, 1:10, 1:20) were used and accordingly, the impedimetric measurements were performed (Figure $S 7$ ). Since low $R_{\mathrm{ct}}$ value with good reproducibility was obtained in the medium of 1:10 (FBS:PBS), it was chosen as the optimum dilution ratio for further experiments.

The hybridization between miRNA-34a DNA probe and miRNA-34a RNA target was performed in FBS medium in the presence of different miRNA-34a target concentrations ranging from 2 to $12 \mu \mathrm{g} / \mathrm{mL}$. The $R_{\text {ct }}$ value was increased till $10 \mu \mathrm{g} / \mathrm{mL}$ miRNA-34a target (Figure S8B) then it leveled off (Figure S8A-g). The detection limit (DL) [33] was estimated in the linear concentration range from 2 to $10 \mu \mathrm{g} / \mathrm{mL}$ (Figure S8B) and found to be $0.826 \mu \mathrm{g} / \mathrm{mL}$ (4.68 pM in $40 \mu \mathrm{L}$ sample) with a regression equation $y=39.826 x-22.071$ with the coefficient of determination $\left(R^{2}\right)$ of $R^{2}=0.992$.

Next, the selectivity of the impedimetric biosensor was tested against miRNA 155 and miRNA $181 \mathrm{~b}$ in the presence of 1:10 FBS: PBS diluted solution the changes at the $R_{c t}$ were accordingly calculated in the case of hybridization in diluted FBS, and the results were compared to the one obtained by pseudo hybridization using miRNA-34a DNA probe (Figure 7). The average $\mathrm{R}_{\mathrm{ct}}$ values were recorded as $861.43 \pm 98.60,605.97 \pm 65.36$, and $673.25 \pm 174.34 \mathrm{Ohm}$ with the RSDs $\% 11.45 \%, 10.79 \%$, and $25.90 \%$ $(\mathrm{n}=3)$ after the hybridization of DNA probe and miRNA-34a, miRNA-155, and miRNA-181b, respectively. $62.4 \%$, increase $R_{c t}$ value were obtained after the hybridization of DNA probe and miRNA-34a. On the other hand, $14.20 \%$ and $27.91 \%$ increase were calculated respectively at the $\mathrm{R}_{\mathrm{ct}}$ value in the case of hybridization with miRNA-155 and miRNA-181b. 


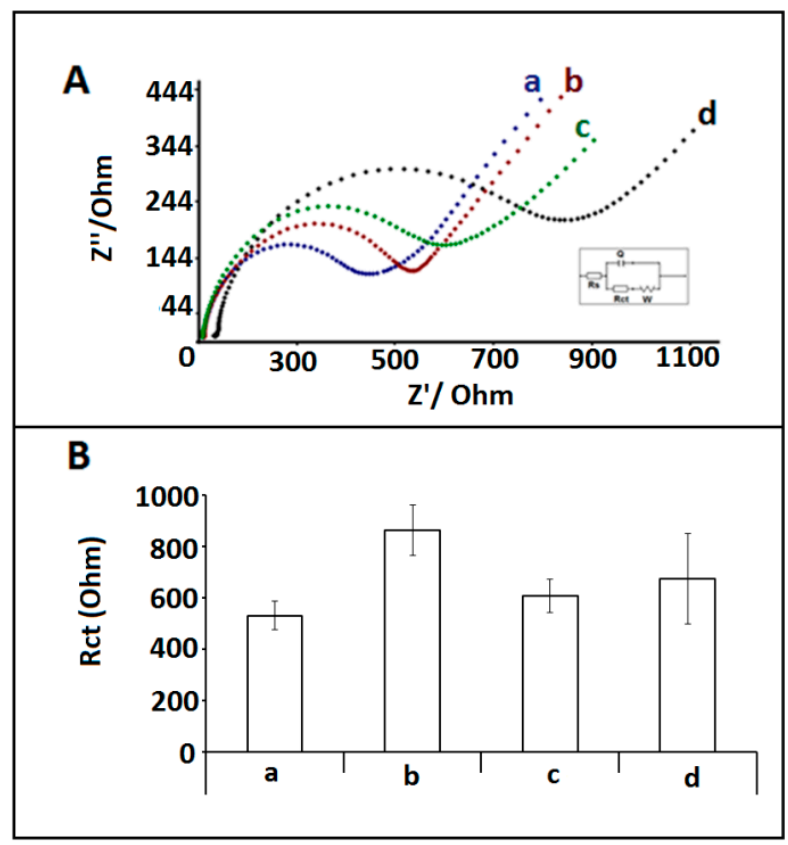

Figure 7. (A) Nyquist diagrams representing the $\mathrm{R}_{\mathrm{ct}}$ values obtained by (a) $1 \mu \mathrm{g} / \mathrm{mL}$ miRNA-34a probe modified /IL/CA/PGE in FBS (1:10), hybridization between $1 \mu \mathrm{g} / \mathrm{mL}$ miRNA-34a DNA probe and $10 \mu \mathrm{g} / \mathrm{mL}$ (b) miRNA-34a target, (c) miRNA-155a, (d) miRNA-181b in FBS (1:10). (B) Histograms representing the $R_{\mathrm{ct}}$ values obtained by (a) $1 \mu \mathrm{g} / \mathrm{mL}$ miRNA-34a probe modified /IL/CA/PGE in FBS (1:10), after hybridization between $1 \mu \mathrm{g} / \mathrm{mL}$ miRNA-34a DNA probe and $10 \mu \mathrm{g} / \mathrm{mL}$ (b) miRNA-34a target, (c) miRNA-155, (d) miRNA-181b in FBS (1:10).

It could be concluded that our impedimetric biosensor based on IL-modified covalently activated disposable PGEs showed a selective behavior to specific miRNA-34a detection even in artificial serum medium due to the highest increase ratio at $R_{c t}$ was recorded after full hybridization of DNA probe with miRNA-34a target.

\section{Conclusions}

Ionic liquid-modified chemically activated graphite electrodes were developed for the first time in the literature, and they were applied for impedimetric detection of miRNA-34a. The characterization of IL/CA/PGEs was performed using not only electrochemical techniques, but also by SEM. Under the optimized experimental conditions, our impedimetric miRNA-34a biosensor presented a good hybridization selectivity against other miRNAs (miRNA-155, and miRNA-181b) even if more than seven bases of these miRNAs were the same with the miRNA-34a target base sequence. There have been many studies [31,34-40] presenting the detection of miRNA using different types of electrochemical transducers/electrodes, and some of these studies were summarized in Table 1. In comparison to the previous reports, our proposed electrochemical biosensor platform presented some advantages; such as, easy-to-handle, cost-effective, fast, disposable electrode surface modification and portable. In this aspect, our biosensor provides a cost-effective assay in contrast to the earlier studies performed using screen-printed electrodes [41], or gold electrodes [42], AuNPs-modified electrodes [43] and some optical biosensor systems [44]. Additionally, the detection of miRNA achieved in both buffer (PBS) and diluted FBS medium within detection limits of $109 \mathrm{nM}$ and $117 \mathrm{nM}$, respectively.

Ionic liquid-modified chemically activated PGEs offer advanced detection methodologies for the detection of nucleic acids. The IL-based disposable sensor platform developed in our study presents great promise for development of low-cost and sensitive biosensing protocol for healthcare monitoring as well as environmental analysis. 
Table 1. Recent studies developed for miRNA detection compared to the present study. Abbreviations: Electrodes: PGE: pencil graphite electrode, SPE: screen printed electrode, GCE: glassy carbon electrode, AuE: gold electrode. Modification materials: GO: graphene oxide, CNF: carbon nanofiber AuNPs: gold nanoparticles, $\mathrm{MgO}$ : magnesium oxide, $\mathrm{MoS}_{2}$ : molybdenum disulfide, IL: ionic liquid, LNA/MB: locked nucleic acid/molecular beacon, CA: chemically activated. Technique: SWV: square wave voltammetry, CV: cyclic voltammetry, DPV: differential pulse voltammetry, EIS: electrochemical impedance spectroscopy.

\begin{tabular}{ccccc}
\hline Electrode & miRNA & Method & DL & Reference \\
\hline GO/CA/PGE & miRNA-34a & EIS & $82.36 \mathrm{nM}$ & {$[31]$} \\
CNFs/SPE & miRNA-34a & DPV, EIS & $3.12 \mu \mathrm{M}$ & {$[34]$} \\
AuNPs/AuE & miRNA let-7d & EIS, CV, SWV, & $0.17 \mathrm{pM}$ & {$[35]$} \\
MWCNT modified GCE & miRNA-155 & CV, DPV & $1.64 \mathrm{fM}$ & {$[36]$} \\
specific biotinylated & miRNA-21 & EIS & $0.3 \mathrm{pM}$ & {$[37]$} \\
DNA/LNA/MB/AuNPs/GCE & miRNA-21 & CV, DPV, EIS & $0.086 \mathrm{fM}$ & {$[38]$} \\
AuNPs/MoS $/$ GCE & miRNA-34a & EIS & $0.20 \mu \mathrm{g} / \mathrm{mL}$ & {$[39]$} \\
PPy-PGE & miRNA-34a & DPV & $1.07 \mu \mathrm{M}$ & {$[40]$} \\
GO/CA/PGE & miRNA-34a & EIS & $0.772 \mu \mathrm{mL} / 0.109 \mu \mathrm{M})$ & This study \\
IL/CA/PGE & & & &
\end{tabular}

Supplementary Materials: The following document is available online at http:/ / www.mdpi.com/1424-8220/18/ 9/2868/s1, Figure S1: Histograms representing the average oxidation signal of (a) PGE (b) CA/PGE, \%IL modified CA/PGE (c) $5 \%$ (d) 10\%, Figure S2: (A) Nyquist diagrams (B) Histograms representing the $R_{c t}$ values obtained by (a) PGE, (b) CA/PGE, 20\% IL modified CA/PGE, (c) $15 \mathrm{~min}$, (d) $30 \mathrm{~min}$, (e ) $60 \mathrm{~min}$. (e) $15 \%$ (f) $20 \%$ (g) $25 \%$ (h) 30\%, Figure S3: Histograms representing the $\mathrm{R}_{\mathrm{ct}}$ values obtained by (a) PGE, (b) CA/PGE, (c) IL/CA/PGE, $1 \mu \mathrm{g} / \mathrm{mL}$ probe modified (a') PGE, ( $\left.\mathrm{b}^{\prime}\right) \mathrm{CA} / \mathrm{PGE},\left(\mathrm{c}^{\prime}\right)$ IL/CA/PGE. Inset was the apparent fractional coverage $\left(\mathrm{Q}_{\mathrm{IS}}{ }_{\mathrm{R}}\right)$ values of $1 \mu \mathrm{g} / \mathrm{mL}$ miRNA-34a DNA probe modified (a) PGE, (b) CA/PGE, (c) IL/CA/PGE, Figure S4: (A) Nyquist diagrams representing the $R_{c t}$ values obtained by (a) CA/PGE, (b) IL/CA/PGE, (c) Hybrid between $1 \mu \mathrm{g} / \mathrm{mL}$ miRNA-34a probe and $10 \mu \mathrm{g} / \mathrm{mL}$ target modified IL/CA/PGE. (B) Histograms representing the $\mathrm{R}_{\mathrm{ct}}$ values obtained by (a) CA/PGE, (b) IL/CA/PGE, (c) Hybrid between $1 \mu \mathrm{g} / \mathrm{mL}$ miRNA-34a probe (d) $0.5 \mu \mathrm{g} / \mathrm{mL}$ probe (e) $1.5 \mu \mathrm{g} / \mathrm{mL}$ probe and $10 \mu \mathrm{g} / \mathrm{mL}$ target modified IL/CA/PGE, Figure S5: Histograms representing the $R_{\mathrm{ct}}$ values obtained by (a) PGE, (b) CA/PGE, 20\% IL modified CA/PGE, pseudo hybridization of $1 \mu \mathrm{g} / \mathrm{mL}$ miRNA-34a DNA probe immobilization onto the surface of IL/CA/PGE in various time (d) $5 \mathrm{~min}$, (e ) $15 \mathrm{~min}$, (f) $30 \mathrm{~min},(\mathrm{~g}) 45 \mathrm{~min}$, after hybridization between $1 \mu \mathrm{g} / \mathrm{mL}$ miRNA-34a DNA probe and $10 \mu \mathrm{g} / \mathrm{mL}$ miRNA-34a target immobilization onto the IL/CA/PGE surface in various time (d') $5 \mathrm{~min},\left(\mathrm{e}^{\prime}\right) 15 \mathrm{~min},\left(\mathrm{f}^{\prime}\right) 30 \mathrm{~min},\left(\mathrm{~g}^{\prime}\right) 45 \mathrm{~min}$, Figure S6: Histograms representing the $\mathrm{R}_{\mathrm{ct}}$ values obtained by (a) PGE, (b) CA/PGE, 20\% IL modified CA/PGE, pseudo hybridization of $1 \mu \mathrm{g} / \mathrm{mL}$ miRNA-34a DNA probe onto the surface of IL/CA/PGE in different time (d) $5 \mathrm{~min}$, (e ) $15 \mathrm{~min}$, (f) $30 \mathrm{~min}$, after hybridization between $1 \mu \mathrm{g} / \mathrm{mL}$ miRNA-34a DNA probe and $10 \mu \mathrm{g} / \mathrm{mL}$ miRNA-34a target immobilization onto the IL/CA/PGE surface in different hybridization time (d') 5 min, $\left(e^{\prime}\right) 15$ min, (f') 30 min, Figure S7: Histograms representing the $R_{c t}$ values obtained by (a) PGE, (b) CA/PGE, 20\% IL modified CA/PGE, pseudo hybridization of $1 \mu \mathrm{g} / \mathrm{mL}$ miRNA-34a DNA probe onto the surface of IL/CA/PGE in different FBS dilution rate (d) 1:1, (e), 1:5, (f) 1:10, (g) 1:20, Figure S8: Histograms representing the $R_{c t}$ values obtained by (a) pseudo hybridization of $1 \mu \mathrm{g} / \mathrm{mL}$ miRNA-34a DNA probe in diluted FBS (1:10), after hybridization between $1 \mu \mathrm{g} / \mathrm{mL}$ miRNA-34a 59 DNA probe and different miRNA-34a target concentrations (b) $2 \mu / \mathrm{mL}$, (c) 4 $\mu \mathrm{g} / \mathrm{mL}$, (d) $6 \mu \mathrm{g} / \mathrm{mL}$ (e) $8 \mu \mathrm{g} / \mathrm{mL}$, (f) $10 \mu \mathrm{g} / \mathrm{mL}$ (g) $12 \mu \mathrm{g} / \mathrm{mL}$. (B) The calibration graph obtained from $\mathrm{R}_{\mathrm{ct}}$ values measured in the presence of different concentration of miRNA-34a target, ranging from $2-10 \mu \mathrm{g} / \mathrm{mL}$, Table S1: According to the CV measurements; average anodic peak currents (Ia) average cathodic peak current (Ic), anodic charge values (Qa) and calculated surface areas (A) of PGE, CA/PGE and \% IL modified CA/PGEs, 5\% to 30\%, Table S2: The $\mathrm{Q}^{\mathrm{IS}}{ }_{\mathrm{R}}$ values obtained using hybrid immobilized IL/CA/PGE at different concentration level of miRNA-34a DNA target from 2 to $12 \mu \mathrm{g} / \mathrm{mL}$.

Author Contributions: A.E. conceived and designed the experiments; E.K. performed the experiments with E.E.; A.E. analyzed the data for writing the paper; A.E., E.E. and E.K. revised the paper.

Funding: This research was funded by Ege University Scientific Research Project Coordination (Project No. 18/FBE/003).

Acknowledgments: A.E. would like to express her gratitude to Ege University Scientific Research Project Coordination (Project No. 18/FBE/003) as the Project Investigator and to the Turkish Academy of Sciences (TUBA) as a Principal member for its partial support.

Conflicts of Interest: The authors declare no conflict of interest. 


\section{References}

1. Wang, J.; Kawde, A.N. Pencil-based renewable biosensor for label-free electrochemical detection of DNA hybridization. Anal. Chim. Acta 2001, 431, 219-224. [CrossRef]

2. Palecek, E.; Bartosik, M. Electrochemistry of nucleic acids. Chem. Rev. 2012, 112, 3427-3481. [CrossRef] [PubMed]

3. Lu, C.-H.; Willner, B.; Willner, I. DNA nanotechnology: From sensing and DNA machines to drug-delivery systems. ACS Nanotechnol. 2013, 7, 8320-8332. [CrossRef] [PubMed]

4. Ping, J.; Wang, Y.; Fan, K.; Wu, J.; Ying, Y. Direct electrochemical reduction of graphene oxide on ionic liquid doped screen-printedelectrode and its electrochemical biosensing applications. Biosens. Bioelectron. 2011, 28, 204-209. [CrossRef] [PubMed]

5. Espinoza-Castañeda, M.; de la Escosura-Munñiz, A.; Merkoçi, A. Nanoparticle/nanochannels-based electrochemical biosensors. In Electrospinning for High Performance Sensors; Springer International Publishing: Cham, Switzerland, 2015; pp. 205-223.

6. Erdem, A. Nanomaterial based electrochemical DNA sensing strategies. Talanta 2007, 74, 318-325. [CrossRef] [PubMed]

7. Erdem, A.; Muti, M.; Mese, F.; Eksin, E. Chitosan-ionic liquid modified single-use sensor for electrochemical monitoring of sequence-selective DNA hybridization. Colloids Surf. B 2014, 114, 261-268. [CrossRef] [PubMed]

8. Yu, P.; Lin, Y.; Xiang, L.; Su, L.; Zhang, J.; Mao, L. Molecular films of water-miscible ionic liquids formed onto glassy carbon electrode: characterization and electrochemical applications. Langmuir 2005, 21, 9000-9006. [CrossRef] [PubMed]

9. Wei, D.; Ivaska, A. Applications of ionic liquids in electrochemical sensors. Anal. Chim. Acta 2008, 607, 126-135. [CrossRef] [PubMed]

10. Wei, Z.L.; Li, Z.J.; Sun, X.L.; Fang, Y.J.; Liu, J.K. Synergistic contributions of fullerene, ferrocene, chitosan and ionic liquid towards improved performance for a glucose sensor. Biosens. Bioelectron. 2010, 25, 1434-1438.

11. Zhang, Y.; Liu, Y.; Chu, Z.; Shi, S.; Jin, W. Amperometric glucose biosensor based on direct assembly of Prussian blue film with ionic liquid-chitosan matrix assisted enzyme immobilization. Sens. Actuators B Chem. 2013, 176, 978-984. [CrossRef]

12. Xi, F.; Liu, L.; Wu, Q.; Lin, X. One-step construction of biosensor based on chitosan-ionic liquid-horseradish peroxidase biocomposite formed by electrodeposition. Biosens. Bioelectron. 2008, 24, 29-34. [CrossRef] [PubMed]

13. Eksin, E.; Muti, M.; Erdem, A. Chitosan/Ionic liquid composite electrode for electrochemical monitoring of the surface-confined interaction between mitomycin C and DNA. Electroanalysis 2013, 25, 1-9. [CrossRef]

14. She, Y.; Tang, Y.; Liu, H.; He, P. Electrochemical determination of hydroquinone using hydrophobic ionic liquid-type carbon paste electrodes. Chem. Cent. J. 2010, 4, 17-25. [CrossRef] [PubMed]

15. Ren, R.; Leng, C.; Zhang, S. A chronocoulometric DNA sensor based on screen-printed electrode doped with ionic liquid and polyaniline nanotubes. Biosens. Bioelectron. 2010, 25, 2089-2094. [CrossRef] [PubMed]

16. Sengiz, C.; Congur, C.; Erdem, A. Development of Ionic Liquid Modified Disposable Graphit Electrodes for Label-Free Electrochemical Detection of DNA Hybridization Related to Microcystis spp. Sensors 2015, 15, 22737-22749. [CrossRef] [PubMed]

17. Bernstein, E.; Kim, S.Y.; Carmell, M.A.; Murchison, E.P.; Alcorn, H.; Li, M.Z.; Mills, A.A.; Elledge, S.J.; Anderson, K.V.; Hannon, G.J. Dicer is essential for mouse development. Nat. Genet. 2003, 35, $215-217$. [CrossRef] [PubMed]

18. Wienholds, E.; Kloosterman, W.P.; Miska, E.; Alvarez-Saavedra, E.; Berezikov, E.; de Bruijn, E.; Horvitz, R.H.; Kauppinen, S.; Plasterk, R.H. MicroRNA expression in zebrafish embryonic development. Science 2005, 309, 310-311. [CrossRef] [PubMed]

19. Hunt, E.A.; Goulding, A.M.; Deo, S.K. Direct detection and quantification of microRNAs. Anal. Biochem. 2009, 387, 1-12. [CrossRef]

20. Tüfekci, K.U.; Öner, M.G.; Meuwissen, R.L.J.; Genç, Ş. The Role of MicroRNAs in Human Diseases. In miRNomics: MicroRNA Biology and Computational Analysis. Methods in Molecular Biology (Methods and Protocols); Yousef, M., Allmer, J., Eds.; Humana Press: Totowa, NJ, USA, 2014; Volume 1107, pp. $33-50$. 
21. Jin, H.Y.; Xiao, C. MicroRNA Mechanisms of Action: What have We Learned from Mice? Front. Genet. 2015. [CrossRef] [PubMed]

22. Waldman, S.A.; Terzic, A. Applications of microRNA in cancer: Exploring the advantages of miRNA. Clin. Transl. Sci. 2009, 2, 248-249. [CrossRef] [PubMed]

23. Bettazzi, F.; Hamid-Asl, E.; Esposito, C.L.; Quintavalle, C.; Formisano, N.; Laschi, S.; Catuogno, S.; Iaboni, M.; Marrazza, G.; Mascini, M.; et al. Electrochemical detection of miRNA-222 by use of a magnetic bead-based bioassay. Anal. Bioanal. Chem. 2013, 405, 1025-1034. [CrossRef] [PubMed]

24. Da Costa Martins, P.A.; Leptidis, S.; Salic, K.; De Windt, L.J. MicroRNA regulation in cardiovascular disease. In Currebt Drug Targets; Bentham Science Publishers: Emirate of Sharjah, UAE, 2010; Volume 11, pp. 900-906.

25. Schonrock, N.; Matamales, M.; Ittner, L.M.; Götz, J. MicroRNA networks surrounding APP and amyloid- $\beta$ metabolism-implications for Alzheimer's disease. Exp. Neurol. 2012, 235, 447-454. [CrossRef] [PubMed]

26. Kilic, T.; Erdem, A.; Ozsoz, M.; Carrara, S. microRNA biosensors: Opportunities and challenges among conventional and commercially available techniques. Biosens. Bioelectron. 2018, 99, 525-546. [CrossRef] [PubMed]

27. Munoz, J.; Montes, R.; Baeza, M. Trends in electrochemical impedance spectroscopy involving nanocomposite transducers: Characterization, architecture surface and bio-sensing. TrAC Trends Anal. Chem. 2017, 97, 201-215. [CrossRef]

28. Cogswell, J.P.; Taylor, J.I.A.; Waters, M.; Shi, Y.; Cannon, B.; Kelnar, K.; Kemppainen, J.; Brown, D.; Chen, C.; Prinjha, R.K.; et al. Identification of miRNA changes in Alzheimer's disease brain and CSF yields putative biomarkers and insights into disease pathways. J. Alzheimer's Dis. 2008, 14, 27-41. [CrossRef]

29. Patel, A.; Boufraqech, M.; Jain, M.; Zhang, L.; He, M.; Gesuwan, K.; Gulati, N.; Nilubol, N.; Fojo, T.; Kebebew, E. MiR-34a and miR-483-5p are candidate serum biomarkers for adrenocortical tumors. Surgery 2013, 154, 1224-1229. [CrossRef] [PubMed]

30. Zhao, J.; Guerrero, A.; Kelnar, K.; Peltier, H.J.; Bader, A.G. Synergy between next generation EGFR tyrosine kinase inhibitors and miR-34a in the inhibition of non-small cell lung cancer. Lung Cancer 2017, 108, 96-102. [CrossRef] [PubMed]

31. Erdem, A.; Eksin, E.; Isin, D.; Polat, D. Graphene Oxide Modified Chemically Activated Graphite Electrodes for Detection of microRNA. Electroanalysis 2017, 29, 1350-1358. [CrossRef]

32. Janek, R.P.; Fawcett, W.R. Impedance spectroscopy of self-assembled monolayers on Au(111): Sodium ferrocyanide charge transfer at modified electrodes. Langmuir 1998, 14, 3011-3018. [CrossRef]

33. Miller, J.N.; Miller, J.C. Statistics and Chemometrics for Analytical Chemistry; Harlow, England: London, UK, 2000; pp. 213-240.

34. Erdem, A.; Eksin, E.; Congur, G. Indicator-free electrochemical biosensor for microRNA detection based on carbon nanofibers modified screen printed electrodes. J. Electroanal. Chem. 2015, 755, 167-173. [CrossRef]

35. Tao, Y.; Yin, D.; Jin, M.; Fang, J.; Dai, T.; Li, Y.; Li, Y.-X.; Pu, Q.; Xie, G. Double-loop hairpin probe and doxorubicin-loaded gold nanoparticles for the ultrasensitive electrochemical sensing of microRNA. Biosens. Bioelectron. 2017, 96, 99-105. [CrossRef] [PubMed]

36. Cai, W.; Xie, S.; Tang, Y.; Chai, Y.; Yuan, R.; Zhang, J. A label-free electrochemical biosensor for microRNA detection based on catalytic hairpin assembly and in situformation of molybdophosphate. Talanta 2017, 163, 65-71. [CrossRef] [PubMed]

37. Azzouzi, S.; Mak, W.C.; Kor, K.; Turner, A.P.F.; Ali, M.B.; Beni, V. An integrated dual functional recognition/amplification bio-label for the one-step impedimetric detection of Micro-RNA-21. Biosens. Bioelectron. 2017, 92, 154-161. [CrossRef] [PubMed]

38. Shuai, H.L.; Huang, K.J.; Chen, Y.X.; Fang, L.X.; Jia, M.P. Au nanoparticles/hollow molybdenum disulfide microcubes based biosensor for microRNA-21 detection coupled with duplex-specific nuclease and enzyme signal amplification. Biosens. Bioelectron. 2017, 89, 989-997. [CrossRef] [PubMed]

39. Mandli, J.; Amine, A. Impedimetric genosensor for miRNA-34a detection in cell lysates using polypyrrole. J. Solid State Electrochem. 2018, 22, 1007-1014. [CrossRef]

40. Isin, D.; Eksin, E.; Erdem, A. Graphene oxide modified single-use electrodes and their application for voltammetric miRNA analysis. Mater. Sci. Eng. C 2017, 75, 1242-1249. [CrossRef] [PubMed]

41. Tran, H.V.; Piro, B.; Reisberg, S.; Nguyen, L.H.; Nguyen, T.D.; Duc, H.T.; Pham, M.C. An electrochemical ELISA-like immunosensor for miRNAs detection based on screen-printed gold501 electrodes modified with reduced graphene oxide and carbon nanotubes. Biosens. Bioelectron. 2014, 62, 25-30. [CrossRef] [PubMed] 
42. Souza, C.D.; Zrig, S.; Wang, D.; Pham, M.C.; Piro, B. Electrocatalytic miRNA Detection Using Cobalt Porphyrin-Modified Reduced Graphene Oxide. Sensors 2014, 14, 9984-9994. [CrossRef] [PubMed]

43. Liu, L.; Jiang, S.; Wang, L.; Zhang, Z.; Xie, G. Direct detection of microRNA-126 at a femtomolar level using a glassy carbon electrode modified with chitosan, graphene sheets, and a poly (amidoamine) dendrimer composite with gold and silver nanoclusters. Microchim. Acta 2015, 182, 77-84. [CrossRef]

44. Vaisocherová, H.; Šípová, H.; Víšová, I.; Bocková, M.; Špringer, T.; Ermini, M.L.; Song, X.; Krejčík, Z.; Chrastinová, L.; Pastva, O.; et al. Rapid and sensitive detection of multiple microRNAs in cell lysate by low-fouling surface plasmon resonance biosensor. Biosens. Bioelectron. 2015, 70, 226-231. [CrossRef] [PubMed]

(C) 2018 by the authors. Licensee MDPI, Basel, Switzerland. This article is an open access article distributed under the terms and conditions of the Creative Commons Attribution (CC BY) license (http:/ / creativecommons.org/licenses/by/4.0/). 